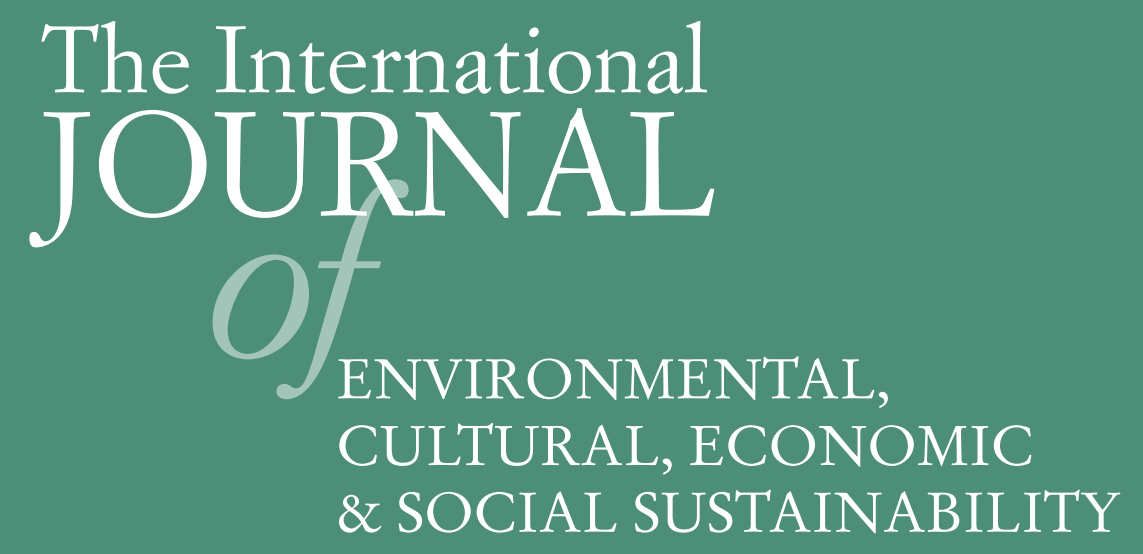

Volume 3, Number 1

Litter and Other Roadside Anomalies: An Exploration of Loss on Australian Highways

Karin Stokes 
THE INTERNATIONAL JOURNAL OF ENVIRONMENTAL, CULTURAL, ECONOMIC AND SOCIAL SUSTAINABILITY

http://www.Sustainability-Journal.com

First published in 2007 in Melbourne, Australia by Common Ground Publishing Pty Ltd www.CommonGroundPublishing.com.

(C) 2007 (individual papers), the author(s)

(c) 2007 (selection and editorial matter) Common Ground

All rights reserved. Apart from fair use for the purposes of study, research, criticism or review as permitted under the Copyright Act (Australia), no part of this work may be reproduced without written permission from the publisher. For permissions and other inquiries, please contact $<\mathrm{cg}$ support@commongroundpublishing.com>.

ISSN: 1832-2077

Publisher Site: http://www.Sustainability-Journal.com

The THE INTERNATIONAL JOURNAL OF ENVIRONMENTAL, CULTURAL, ECONOMIC AND SOCIAL SUSTAINABILITY is a peer refereed journal. Full papers submitted for publication are refereed by Associate Editors through anonymous referee processes.

Typeset in Common Ground Markup Language using CGCreator multichannel typesetting system http://www.CommonGroundSoftware.com. 


\title{
Litter and Other Roadside Anomalies: An Exploration of Loss on Australian Highways
}

\author{
Karin Stokes, Central Queensland University, Queensland, Australia
}

\begin{abstract}
Review of Australian attitudes to three types of roadside signs of habitat disturbance - littering, road-kill and roadside memorials. Discussion of the invisibility of the perpetrators and the effects of campaigns and policies to circumvent continuing destruction of lives and habitat, and how these interconnect with contemporary road usage.
\end{abstract}

Keywords: Litter and Littering, Road-kill, Roadside Memorials

\section{Introduction}

$\mathrm{A}$ USTRALIANS ARE OBSESSED with the motorcar and have a 'culture of automobility' mandated by the isolation of country roads and the long distances between major urban centres (Simpson 2006). Vehicles are means to mobility and survival, giving drivers the illusion of power and freedom, yet they are also the means for dissemination of litter, and for the destruction of human and animal life. The greater the incursion into a region, the more numerous the animal and human fatalities, and the greater the incidence of littering. So the problems for governments are how to encourage an alternate use for road verges, and how to preserve life. This paper will present the issues involved in three types of road-verge use - for litter, memorials, and as sites for road-kill - and suggest a modified paradigm for dealing with these issues.

\section{Litter and its Campaigns}

Litter is seen to be any solid waste object that can be held in a person's hand and is left behind or placed in an inappropriate location (Adelaide City Council 2006). It can be classified under five headings: Glass, Cans, Paper, Plastics and 'Other', which includes truck tyres, ice-cream sticks and cigarette lighters, but excludes food. According to Bell (2006), there has been a dramatic increase in the proliferation of litter along highways, so much so that it is exceeding local council clean-up capabilities. The several decades-long anti-litter campaigns encouraged by governments around Australia have resulted in human litter-disposal patterns that favour binning, yet all age demographics over 15 years will litter rather than venture as little as ten meters out of their way to dispose of litter appropriately (Adelaide City Council 2006; E.I.M.M. 2006).
In Queensland, highway littering has resulted in the 'Adopt-a-Road' project (K.A.B.Q. 2006), deploying coordinated litter cleanups along a community's streets and roads, but these projects must be approved and are unlikely to function far from residential communities. Litter leaves a lasting impression on the bushland beside many highways, particularly cigarette butts, which are the most littered item across Australia. Smokers rarely consider that dropping butts is littering, and are largely oblivious to the environmental consequences of such activity (I.E.M.M. 2006). Glowing butts, dropped onto dry roadside litter in rural and forested areas can start fires with devastating consequences (Chapman 1999), as can reflection of sunlight through discarded glass. How frequently this occurs is largely unknown, but Australia's fires have, in recent decades, become more threatening to human life and habitation, this increase also caused through the continual spread of the population and its demands for high-speed sealed roads to remote communities.

Strategically placed litter traps testify to the preponderance of cigarette butts in waterways, to which much additional litter is carried by storm runoff from urban areas. Such traps serve beaches as well as the more littered riverbanks and local shopping precincts. It is unsurprising then that a state-sponsored stormwater quality review found neither education nor participation campaigns produced the major shifts required to facilitate long-term litter reduction in waterways (Taylor, Fletcher \& Lewis 2003). Public eating and drinking alongside waterways has become common with consequent increased littering, particularly of food and drink containers, primarily due to laziness and indifference (Southern Councils of Tasmania 2006; Sustainability Victoria 2006). Western Australia has a regular manual litter collection program for its urban and surrounding waterways and roads, and despite the cost and labour intensity of such enterprise (West Australian Govern-

THE INTERNATIONAL JOURNAL OF ENVIRONMENTAL, CULTURAL, ECONOMIC AND SOCIAL SUSTAINABILITY, VOLUME 3, NUMBER 1, 2007 
ment 2006), the need for such a service continues and is increasing.

It appears that a mixture of educational, antecendent and consequent strategies are necessary to establish behaviour pattern changes resulting in litter reduction. Yet the social nature of littering ensures that wherever people gather together in public spaces, litter ensues. Thus it is that travelling along Australian highways produces an expectation that increasing litter equates to a local community, yet the litter most common along outback highways seems to be not so much hand-held discards as blown truck tyres. These proliferate alongside roads that remain unbitumened, or have long straight stretches, where speed is a factor in tyre disintegration. To date no research has been conducted into this non-degradable waste that is found scattered along many tens of meters of roadside at a time for each tyre so destroyed. 'Dead' tyres also often accompany another form of human-sourced roadside anomaly, the memorial.

\section{Roadside Memorials as Alternative Litter}

Roadside memorials are the public markers of private trauma and grief, and turn public land into private sacred space, in an attempt to find culturally appropriate symbols to express what has been an 'invisible death' in an increasingly secular society (Clark \& Franzmann 2002). As many as $20 \%$ of road deaths are now being commemorated in this way (Clarke \& Doogue 2006), emphasizing a yearning for a nonindigenous sense of emplacement and belonging in the landscape (Simpson 2006). However, it is rare to know of the actual details prompting the commemoration, and rarer still to see any people actually at the sites (Smith 1999), yet despite their illegality, they continue to proliferate and can present yet another road hazard, and these become a nightmare to regulate (Clarke \& Doogue 2006).

Car crashes are presented as an everyday and acceptable form of violence (Simpson 2006), and whilst some memorials serve as a warning to other road users (Monger 1997), they also function as conservative memorials of youth machismo, of heroic aggression, of disregard for safety and egocentrism (Hartig \& Dunn 1998). Uncontrolled proliferation of individual memorials evoke visions of a 'perpetual graveyard' (McLennan 2006); yet in practice, memorials are only removed when they have fallen into neglect or are considered to be either a traffic or pedestrian hazard (Smith 1999), or have been vandalised (Hartig \& Dunn 1998). Council responses to their erection have usually been sympathetic, although a growing number have placed limits on the size, shape and composition of memorials (Buchan 2003). This raises the issue, for local governments, of what to do about the inappropriate location of some tributes.

In South Australia, standardised markers are placed at fatality sites, but these are simply marking road fatalities and crashes, not a system that memorialises victims (McLennan 2006), so fails to address the social reasons behind the practice. Instead, it is seen to force an impersonal bureaucratic standardization onto a personal practice. The erection of roadside memorials allows survivors and friends to negotiate an 'intimately tragic and unexpectedly traumatic event' (Clark \& Franzmann 2002) but fails to answer why the roadside is chosen to create a sacred space in the first place, since this is not usually the place of death. Instead, it may indicate that the place is rich in significance for those undertaking the memorialisation.

Present day memorials and shrines also serve as a silent criticism of the state and safety of Australian roads (Smith 1999) and so are not favoured by road authorities, who lobby in favour of their limited lifespan. They also speak to the lack of spirituality in secularised Australian funerary practices and the lack of spiritual comfort obtained from religious mourning practices (Clark \& Franzmann 2002). As an educative site, the memorial serves as both a warning and an object-lesson. It is therefore not unlikely that memorial myths attached to sites will stimulate redesign of vehicles and roadways or become future place-names, but McLennan (2006) cautions that memorialisation is not always positively sanctioned in Australian society. Signs or displays of grief are often regarded as psychopathological when they exceed certain parameters.

The high road fatality rate of young men in Australia has its correspondences in other Western countries. An example can be seen in an enterprising American's review of drug- and alcohol-affected, speed- and inexperience-related stories backgrounding US roadside memorials, and whilst in no way an objective enterprise, intends a disparagement of their claimed spiritual significance (Curless 2006)). Perhaps cynicism such as this explain why, once erected, many roadside memorials are left untended and forlorn until they are destroyed or moved. Our ambivalence towards motor vehicle crashes, and our willingness to risk violent death will ensure, however, that not just human fatalities occur.

\section{Roadkill}

Hundreds of thousands of native and feral animals are killed each year on Australian roads, creating a high social and economic cost. The exact magnitude of the problem is as yet unascertainable since many carcases are removed by scavengers, disintegrate rapidly or the animals die away from road verges 
and so are not identified as road-kill casualties. Certainly, road-kills are found more frequently in 'hotspots', areas such as gullies and heavily wooded stretches, and following recent drought conditions. Red kangaroos prefer open grasslands, magpies ridges and possums treed hills (Taylor \& Goldingay 2004; Klöcker, Croft \& Ramp 2006) and kangaroos are frequently killed at road curves and along stock races (Croft \& Ramp 2006). Stock races are fences running along roadsides, which direct sheep and cattle into a concentrated area for easier handling. They are fertile and highly attractive to kangaroos, but also restrict their escape routes from oncoming vehicles. In times of drought, the frequency of kangaroo road-kills was found to have increased markedly at such lush roadside verges (Coulson 1989).

Longitudinally, the seasonal frequency of kangaroo road-kills was found by Coulson's (1989) study to be inversely proportional to the rainfall of the previous season, a finding replicated in Klöcker, Croft and Ramp's (2006) study. The bias found by Coulson, towards male kangaroo road-kills, was not repeated in the Klöcker, Croft \& Ramp study, although males were considered at higher risk due to their lengthier grazing patterns. Of more importance were the road attributes, the speed of the vehicle and driver behaviour, as few drivers take evasive action to prevent animal collisions at curves (Bender 2001), where animals are often not noticed until they loom in front of the speeding vehicle.

Recent research has attempted to determine what animals do at the approach of a car, finding that this varies markedly across species (Klöcker, Croft \& Ramp 2006), location and time of day (Willis 2003; Croft \& Ramp 2006). Lunar phases affect mobilities of animals such as kangaroos (Coulson 1982) as do seasonal changes (Taylor \& Goldingay 2004; Croft $\&$ Ramp 2006). Certainly, the numbers and frequencies of 'automobilities', that is, vehicular movements (Michael 2004), through rural areas has a direct relation to the overall number of road-kills (Coulson 1989; Klöcker, Croft \& Ramp 2006). Small feral and pest species such as foxes, cats and cane toads, readily utilise road verges for their own travel (Goosem 2005) yet may not, due to their size, be readily identifiable from a moving vehicle, particularly at night, when many of these species are abroad. The carcases of such small creatures, as well as of birds, rarely remain at the roadside for long, courtesy of airborne as well as land-based scavengers (Coulson 1982). Above all, there is a lack of accurate data on the number of animals killed every year, road kill black spots and animal behaviour near roads (Kearney 2004).

One ameliorative measure would involve highway design and structure. It is essential that both environ- mental and highway safety aspects be considered in road construction, as roads not only alter the structure of the landscape, they also fragment habitats and disrupt ecological processes (Saunders, Hobbs \& Margules 1991; Merriam \& Wegner 1992; Collinge 1996; Kahrig \& Grez 1996; Laurance 1997; Laurance et al 1997; Laurance et al 1998; Wigley \& Roberts 1997; Scott 1999, Kearney 2004). Overpasses and underpasses offer some solution to habitat fragmentation, but run the risk of becoming a predator's 'lunch-box', as small mammals traverse them (Taylor \& Goldingay 2003; Goodem 2005). Furthermore, it was found that the size of the openings and types of vegetation available at culverts is important in attracting animals and encouraging use of the underpasses, but further research is needed into the distance threshold beyond which animals will not use such road underpasses.

Other remedies, such as the Shu Roo electronic signalling device attached to cars traversing kangaroo territory, have been proven ineffective in deterring kangaroo use of roads, and so in preventing macropod-vehicular collisions (Bender 2001). Diversionary feeding areas and fences have proven counter-productive (Goosem 2005; Klöcker, Croft \& Ramp 2006), as the feeding areas attract predators and fences are routinely and easily destroyed by the larger animals, and can maim the smaller ones. Roadside warning signs have little impact on vehicular speed, although the presence of road-kill will generally slow drivers for a considerable distance (Goosem 2005). This brings up the question of the felicity of routine council removal or destruction of carcasses from the roadside, because drivers take more care when road-kill is evident. Willis (2003) and Kearney (2005) have ascertained that the most effective method of repelling animals from highways is to use dog urine as a deterrent, but this requires frequent respraying and is likely to have a species-specific response, therefore this remedy is useful and affordable only if applied in relatively small areas and over restricted periods (Klöcker, Croft \& Ramp 2006).

Road-kill has a high social and economic cost to all Australians, being heavily implicated in vehicle insurance premiums (Kearney 2004). However, the illegality of generalised harming or killing of kangaroos still rarely translates into motorist intervention in the dying process or rescue of macropods or their offspring (Kangaroo Rescue 2006). Furthermore, relatively few macropod-vehicle collisions are ever reported to police, as insurance companies do not require this additional assessment for their claim procedures (Coulson 1982; Goosem 2005). At present there is no compulsion for drivers to aid or report an injured animal, so existing casualty records are only estimates of the number of road casualties. As animals are easily startled by the sudden approach 
of a speeding vehicle, drivers may have little option but to run into an animal if it crosses his/her path. Safety of passengers, the road conditions, the presence of curves and other traffic, and the driver's state of alertness and response efficiency all contribute to the outcome of an encounter between animobilities and automobilities. Similarly, fuel efficiency in the use of heavy protection devices such as bull bars, and the costs of road maintenance crews for disposal of carcases, all involve personal and community costs which encourages an approach to the subject from the economic perspective alone (Klöcker, Croft \& Ramp 2006). All these debates take precedence over other road-kill issues.

Unfortunately, the decomposing evidence of Australia's national symbol alongside its roads may adversely affect the economic benefit of visits by tourists to rural areas. Whilst the preferential grazing by kangaroos at roadsides may permit tourists to view them in their 'natural' environment, the very means of such viewing, the increasing automobilities involved, ensure that individual animals are unlikely to survive for long.

\section{Discussion}

Using Latour's (1993) notion of the 'modern constitution', that is, keeping a cultural separation between the human and non-human, presents us with quite standardized views about what sort of animal belongs in what sort of space. It also allows a hierarchical view of non-humans according to their utility for humans. The destruction of sheep on a rural roadway by a speeding truck will be felt as an economic loss that cannot be imagined in the loss of a kangaroo, wombat, echidna or koala. Domestic animals occupy space that differs from that of the animals found in native bush, even if it is geographically in the same area. The ideological boundaries created by humans for the spaces to be inhabited by themselves and animals are territories without border guards. Animals and humans alike move across these territorial boundaries (Wolch \& Emel 1998), and thus the two trajectories-humans-in-their-cars and animals-intheir-ecosystems - interact to generate road-kill.

Michael (2004) has pointed to the different perceptions of road-kill as pertaining only to mammals and birds rather than including insects, arachnids or other micro-fauna. The presence of squashed insects on a car's windscreen is never considered evidence of road-kill, but only of nuisance and as an impediment to the human enjoyment of automobility. Michael also posited that road-kill instances give rise to comedy for the human survivors of these encounters. Human automobility and animal mobilities intersect in ways that encourage survivors to find the imprint of vehicle upon road-kill bodies humorous, both as a way of debriefing from the incident, and as heroic narrative. The 'moving fuzzy borderlands' of road verges inhabited by admixtures of humans, animals and vehicular technologies are not easily separated into safe zones (Michael 2004), but can easily be kept separate in culture, so that human use obtains priority.

Efforts to discourage animal use of these borderlands have consistently failed in Australia as animals adapt to the forage and freedom of movement offered by road verges. Animals accommodate and habituate to artificial sounds and lights, so that the search has begun for natural alarm signals that can be replicated to produce the desired effect of keeping animals away from road verges (Bender 2005), but these, too, must be species-specific. The upgrading of road surfaces to distant communities has also seen an increase in accessibility for both residents and visitors, and therefore more opportunities arise for littering, crash damage and death. Road-kill is not regarded with the reverence accorded a human casualty, nor with the unthinking disregard for litter evidenced in its disposal and thus has no special place in Australian culture that would advance its reduction. The warnings of ecologists are heeded only after the problems reach levels of near-irreversibility, and solutions remain haphazard and uncoordinated. Warning signs on roads can only offer a general caution to human road users, because Australia's outback roads are isolated and independent witnesses to litter and casualties exceedingly rare.

Other road users will generally only halt their journeys to assist at the site of a human casualty, or when the incident results in vehicular damage. If the Canadian experience of positively-modified driver responses to the physical presence of road-killed deer can be extrapolated to the Australian condition, then some visible indicator of a road-kill should produce a similar effect. Australia, however, is a hot country, where road-kills quickly become a health hazard, and so leaving the carcases in situ would not be an appropriate action. Similarly, litter can promote an increase in road-kills due to its attraction for scavenging animals to road verges where litter accumulates. Or litter can destroy bush and property through its flammability or toxicity. Road-kill and litter is usually left for the appropriate authorities, so it is council labour which removes or destroys the road-kill carcases, and special periodic community effort is made to clean specific roads and waterways of their litter loads. Such repetitive effort does nothing to reduce or obviate the effects of these deleterious practices, and can even be considered to be exacerbating them by helping make both litter and road-kill invisible. Invisibility aids in the dichotomising of human non-human relations. 
Education strategies alert human populations to the dangers of specific actions, but as shown by the numerous anti-litter campaigns, preventative and punitive measures must also be adopted for any success to be achieved. In the case of littering, such educative, punitive and preventative strategies have been put in place in classrooms across Australia, and have been advertised on television and through signage in 'hot-spots'. The success of these strategies has been evidenced in the care with which Australian children dispose of their litter. Unfortunately, adults are less inclined to be concerned about the punitive aspects, and so may just as easily disregard anti-littering instructions as obey them.

Education, in the form of driver's licensing or general advertising, does little to prepare drivers to deal with the impact of their vehicles with bodies, nor does it have any effect on adult littering behaviours. Signage is easily ignored, and since the incidence of both littering and road-kill per vehicular trips is low, few witnesses will report such instances. Again, it is the conception that human life is the only really important facet of road safety, which ensures that legislative efforts are turned towards to preservation of individual humans rather than animals or their habitats. As towns become larger and are more easily reached by road, more evidence of the passing of cars is seen, necessitating expensive and timeconsuming clean-up activities. Education of drivers about environmental and habitat issues would seem a logical choice to offset the incidences of road-kill and littering, but the issue of what will be taught, and how has not been considered.

Any technique adopted to solve the issues of human incursion into what is seen as otherwise pristine or 'natural' areas, will of necessity, be expensive and difficult to achieve. Physical indicators, like roadkill bodies, or roadside memorials, would offer an alternate warning device to the motorist of road-kill histories and potentialities along any given stretch of road. However, this would also demand that humans regard the sites of road-kill as sacred in a way similar to the attitudes adopted towards roadside memorials. As the incidence of littering has shown, however, this is hardly likely to occur, as it is only minute areas, those associated in survivors' minds with people killed at or near those sites, which are considered sacred, and then only for those who were intimates of the deceased. All other areas of the roadway are considered common property, so a 'freeriding' approach to the care of the roadside is the most usual response. Unlike the traditional Australian, modern Australians do not hold the land as sac- red. Land is valuable for its utility to modern Australians, and animals that live upon it are there only on sufferance. With such attitudes, Australians are ensuring that the resultant loss of fauna and the pollution of their habitats will impinge upon the image of this country as a tourist destination. If Australians are indeed to develop responsibility toward the land and all its inhabitants, we must change our attitudes on 'wildlife', and develop more ecologically focused, less anthropocentric ways of sharing this country.

\section{Conclusion}

Litter, road-kill and roadside memorials are found on many roads around Australia, and their presence continues to increase with increasing numbers of automobitiy incursions into previously remote areas of the country. There are lessons to be learned from the various methods used to deal with these roadside anomalies, but to date Australians have failed to emulate the example of countries whose roadside verges remain unlittered, whose wildlife is cared for, or whose human road fatalities are commemorated in ways meaningful to the whole community. Australians enjoy a 'free-rider' approach to roadside anomalies because of distances between communities and the limited chances of being observed, particularly in the acts of littering or creating road-kill. Moreover, legal sanctions to such behaviours depend upon proofs which are both difficult to establish, and are meaningful to legislator and perpetrator alike. Memorialisation of road-kills in the manner used for human road fatalities remains outside the perspectives of most Australians, and whilst many will condemn littering's unsightliness, few people will modify their own behaviour unless knowingly observed by others. Implementation of methods to circumvent the consequent destruction of habitat remains a scattered and ad hoc approach, dependant upon the goodwill of local communities, and then only for their immediate environs. Community attitudes and legislative intentions have not yet produced a viable or workable solution to these problems. Above all, there needs to be a paradigm shift that enables Australians to develop a pride in their country that stems from a reverence toward the land, its inhabitants and their environments. It is likely though, that solutions will emerge only after Australians' roadside habits have become larger economic problems. Unfortunately, the cynicism of the Australian post-modern free-rider will not foster relevant attitudinal changes, nor move towards solutions in the near future.

\section{References}

----- (2006) Adelaide City Council: Litter Reduction Project, viewed on $10^{\text {th }}$ October, 2006 at $h t t p: / / w w w . a d e l a i d e c i t y c o u n-$ cil.com/council/programs/litter_reduction_whatis.asp 
----- (2006) The Australian: Man dies in freak kangaroo accident, viewed on $19^{\text {th }}$ October, 2006 at http://www.theaustralian.news.com.au/story/0,20867,20596669-5006789,00.html

Bell, Paul (2006) Roadside rubbish: taking over, ABC Brisbane, Madonna King interviewing, viewed on $6^{\text {th }}$ November, 2006 on http://www.abc.net.au/brisbane/stories/s1721762.htm

Bender, Helena (2001) Deterrence of kangaroos from roadways using ultrasonic frequencies- efficacy of the Shu Roo, a report to NRMA Insurance Limited, Royal Automobile Club of Victoria, Road Traffic Authority of New South Wales, Transport South Australia, viewed on $18^{\text {th }}$ November, 2006 at http://www.bees.unsw.edu.au/school/researchstaff/ramp/shuroofinal.pdf

Bender, Helena (2005) Effectiveness of the Eastern Grey kangaroo foot thump for deterring conspecifics, Wildlife Research, Vol. 32, pp. 649-655.

Buchan, Phil (2003) Policy: Port Stephens Roadside Tributes and Memorials, viewed $6^{\text {th }}$ October, 2006 at http://www.portstephens.local-e.nsw.gov.au/files/1220/File/Roadside\%20Tributes\%20and\%20Memorials.pdf\#search $=\% 22$ roadside $\% 20$ memorial $\% 20$ crosses $\% 22$

Chapman, Simon (1999) Where there's smoke, there's fire, Tobacco Control, Iss. 8, pp. 12-13. viewed on $13^{\text {th }}$ November, 2006 at http://tc.bmjjournals.com/cgi/content/full/8/1/12

Clark, Jenny \& Franzmann, Majella (2002) Roadside Memorials, ABC Religion, viewed $16^{\text {th }}$ November, 2006 at http://www.abc.net.au/religion/stories/s1000839.htm

Clark, Jennifer (2006) Roadside Memorials, ABC Compass, Geraldine Doogue interviewing, viewed $16^{\text {th }}$ November, 2006 at http://www.abc.net.au/compass/s1676055.htm

Collinge, S.K. (1996) Ecological consequences of habitat fragmentation: implications for landscape architecture and planning, Landscape and Urban Planning, Vol. 36, pp. 59-77.

Coulson, Graeme M. (1982) Road-Kills of Macropods on a Section of Highway in Central Victoria, Australian Wildlife Research, Vol. 9, pp. 21-26.

Coulson, Graeme M. (1989) The Effect of Drought on Road Mortality of Macropods, Australian Wildlife Research, Vol. 16 , pp. 79-83.

Curless, Jason (2006) Roadside Memorials, viewed on $23^{\text {rd }}$ December, 2006 at http://www.porkjerky.com/rip.htm

---- (2006) Environmental Indicators for Metropolitan Melbourne, Litter, viewed on $5^{\text {th }}$ November, 2006 at $h t$ tp://www.aius.org.au/indicators/sectiontype.cfm?ThemeID $=11 \&$ SectionTypeID $=2$

Fahrig, L. \& Grez, A.A. (1996) Population spatial structure, human-caused landscape changes and species survival, Revista chilena de historia natural, Vol. 69, pp. 5-13.

Goosem, Miriam (2005) Cutting Australia's Roadkill, Co-operative Research Centres Association, viewed on 6th December 2006 at $h t t p: / / w w w . c r c a . a s n . a u / p r e s s+r e l e a s e s / 2005 / 2005-31-05 . h t m$

Hartig, K.V. \& Dunn, K.M. (1998) Roadside Memorials: Interpreting New Deathscapes in Newcastle, New South Wales, Australian Geographical Studies, Vol. 36(1), pp. 5-20.

----- (2006) Kangaroo Rescue, viewed $7^{\text {th }}$ December, 2006 at http://www.kangaroo-rescue.com/about_us.html

Kearney, Christine (2004) Roadside assistance for native animals, viewed $23^{\text {rd }}$ November, 2006 at http://www.unsw.edu.au/news/pad/uniken/uniken0304/page09.html

----- (2006) Keep Australia Beautiful Queensland, Adopt-a-Road, viewed on $5^{\text {th }}$ November, 2006 at http://www.keepaustraliabeautiful.org.au/qld/01_cms/details.asp? $I D=8$

Klöcker, Ulrike, Croft, David B. \& Ramp, Daniel (2006) Frequency and causes of kangaroo-vehicle collisions on an Australian outback highway, Wildlife Research, Vol. 33(1), pp. 5-15.

Latour, B. (1993) We have never been modern, Hemel Hempstead: Harvester Wheatsheaf.

Laurance, W.F. (1997) Responses of mammals to rainforest fragmentation in tropical Queensland: a review and synthesis, Wildlife Research, Vol 24, pp. 293-312.

Laurance, W.F., Laurance, S.G., Ferreira, L.V., Rankin-deMerona, J.M., Gascon, C. \& Lovejoy, T.E. (1997) Biomass collapse in Amazonian forest fragments, Science, Vol. 278, pp. 1117-1118.

Laurance, W.F., Ferreira, L.V.,, Rankin-deMerona, J.M. \& Laurance, S.G. (1998) Rainforest fragmentation and the dynamics of Amazonian tree communities, Ecology, Vol. 79(6), pp. 2032-2040.

McLennan, Ali (2006) Roadside Memorials - Devotion or Distraction?, viewed $18^{\text {th }}$ November, 2006 at http://www.scu.edu.au/schools/arts/media/showcase/journalism/DevotionDistraction.html

Merriam, G. \& Wegner, J. (1992) Local extinctions, habitat fragmentation, and ecotones, in A.J. Hansen \& F. diCastri (eds.) Landscape Boundaries: Consequences for Biotic Diversity and Ecological Flows, New York: Verlag.

Michael, Mike (2004) Roadkill: Between Humans, Nonhuman Animals, and Technologies, Society \& Animals, Vol. 12(4), pp. 277-298.

Monger, George (1997) Modem Wayside Shrines, Folklore, Iss. 108, pp. 113-14.

Saunders, D.A., Hobbs, R.J. \& Margules, C.R. (1991) Biological consequewnces of ecosystem fragmentation: a review, Conservation Biology, Vol. 5(1), pp. 18-32.

Scott, J.M. (1999) Vulnerability of forested ecosystems in the Pacific northwest to loss of area, in J.A. Rochelle, L.A. Lehmann \& J. Wisniewski (eds.) Forest Fragmentation: Wildlife and management implications, New York: Brill.

Simpson, Catherine (2006) Antipodean Automobility and Crash: Treachery, Trespass and Transformation of the Open Road, Australian Humanities Review, Iss. 39-40 September.

Smith, Robert James (1999) Roadside Memorials—Some Australian Examples - Critical Essay, Folklore, Annual, viewed $10^{\text {th }}$ December 2006 at http://www.findarticles.com/p/articles/mi_m2386/is_1999_Annual/ai_55983656 
----- (2006) Southern Councils of Tasmania - Southern Waste Strategy Authority, Littering, viewed on $6^{\text {th }}$ November, 2006 at http://www.southernwaste.com.au/littering/

---- (2006) Sustainability Victoria, Understanding Littering and Binning Behaviour, view on $6^{\text {th }}$ November, 2006 at http://www.sustainability.vic.gov.au/www/html/784-1-understanding-littering--binning-behaviour.asp

Taylor, André, Fletcher, Tim \& Lewis, Justin (2003) Evaluation of Non-structural Measures for Stormwater Quality Improvement, Monash University Engineering, viewed on $6^{\text {th }}$ November, 2006 at http://iswr.eng.monash.edu.au/research/projects/evaluation

Taylor, Brendan D. \& Goldingay, Ross L. (2003) Cutting the carnage: wildlife usage of road culverts in north-eastern NSW, Wildlife Research, Vol. 30, pp. 529-537.

Taylor, Brendan D. \& Goldingay, Ross L. (2004) Wildlife road-kills on three major roads in north-eastern NSW, Wildlife Research, Vol. 31, pp. 83-91.

----- (2006) West Australian Government, Non-structural controls Best Management Practice Guidelines, viewed $6^{\text {th }}$ November, 2006 at http://portal.water.wa.gov.au/portal/page/portal/dow/ADMIN_CONTENT/STORMWATER/Manual/BMP2.2.3.pdf

Wigley, T.B. \& Roberts, T.H. (1997) Landscape-level effects of forest management on faunal diversity in bottomland hardwoods, Forest Ecology \& Management, Iss. 90, pp. 141-154.

Willis, Paul (2003) Road Kill Science, Catalyst: ABC TV Science, viewed on $5^{\text {th }}$ November 2006 at http://www.abc.net.au/cgi-bin/common/printfriendly.pl?/catalyst/stories/s861563.htm

Wolch, J., \& Emel, J. (1998) Animal geographies: Place, politics and identity in the natu r e-cultu r e borderlands, London: Verso.

\section{About the Author}

Karin Stokes

Began nursing in 1968, and continued until 2004 when I undertook Honours in sociology. Initially interested in environmental science, I discovered I had a particular leaning towards sociology, and have since begun a $\mathrm{PhD}$ in this field. I am currently studying the social role of colour in Western society, a field which has not been attempted previously and which engenders resistance from hegemonic academics. This resistance appears strongly gender-based and so will inform my final thesis. I continue to develop my interest in environmental issues, particularly those associated with Australian society's impact on the Australian landscape, its waterways and urban communities. 



\section{THE INTERNATIONAL JOURNAL OF ENVIRONMENTAL, CULTURAL, ECONOMIC AND SOCIAL SUSTAINABILITY}

\section{EDITORS}

Amareswar Galla, Australian National University, Australia.

Mary Kalantzis, University of Illinois, Urbana-Champaign, USA.

\section{EDITORIAL ADVISORY BOARD}

Dang Van Bai, Ministry of Culture and Information, Vietnam.

Diane Bell, The George Washington University, Washington DC, USA.

Richard M. Clugston, Center for the Respect of Life and the Environment, and University Leaders for a Sustainable Future, Washington DC, USA.

Bill Cope, University of Illinois, Urbana-Champaign, USA.

John Dryzek, Australian National University, Canberra, Australia.

Robyn Eckersley, University of Melbourne, Australia.

Steven Engelsman, Rijksmuseum voor Volkenkunde, The Netherlands.

John Fien, RMIT University, Melbourne, Australia.

Steve Hemnett, University of South Australia, Australia.

Paul James, RMIT University, Melbourne, Australia.

Lily Kong, National University of Singapore, Singapore.

Thangavelu Vasantha Kumaran, University of Madras, India.

Jim McAllister, Central Queensland University, Australia.

Helena Norberg-Hodge, The International Society for Ecology and Culture (ISEC).

Peter Phipps, RMIT University, Melbourne, Australia.

Koteswara Prasad, University of Madras, India.

Judy Spokes, Cultural Development Network, Melbourne, Australia.

Manfred Steger, Illinois State University, USA and RMIT University, Australia.

David Wood, University of Waterloo, Canada.

Lyuba Zarsky, RMIT University, Australia, and Tufts University, USA.

Please visit the Journal website at http://www.Sustainability-Journal.com for further information:

- ABOUT the Journal including Scope and Concerns, Editors, Advisory Board, Associate Editors and Journal Profile

- FOR AUTHORS including Publishing Policy, Submission Guidelines, Peer Review Process and Publishing Agreement

\section{SUBSCRIPTIONS}

The Journal offers individual and institutional subscriptions. For further information please visit http://ijs.cgpublisher.com/subscriptions.html. Inquiries can be directed to subscriptions@,commongroundpublishing.com

INQUIRIES

Email: cg-support@commongroundpublishing.com 